\title{
EVALUATION OF DIRECT CURRENT ELECTRIC POWER SYSTEMS OF THE AIRCRAFT BASED ON CHARACTERISTICS OF A TRANSIENT STATE
}

\section{Tomasz TOKARSKI}

Air Force Institute of Technology, 01-494, Warszawa 46, Księcia Bolesława 6, e-mail: tomasz.tokarski@,itwl.pl

\section{Summary}

This publication describes the aim and essence of testing transient states of direct current electric power systems in relation to normative characteristics of a transient state. The above diagnostic tests of the given direct current nodes of the aircraft enable to quickly and efficiently determine the capability of its electric power systems to the selfregulation of direct current voltage. Many years of research of aircraft conducted in the Air Force Institute of Technology (ITWL) confirm that the ageing of power network elements impacts the deterioration of the parameters of voltage of transient state. On the basis of the results of on-ground tests of the Su-22 aircraft engine, the obtained model parameters of transient states were presented in subsequent years of its operation, which confirms the abovementioned statement. There were also presented the selected results of tests performed during the follow-up overhaul of Su-22 aircraft with exceeded permissible normative thresholds of the change of voltage amplitude values by the step increase of load (decaying impulses). The determined reasons for detected malfunctions were the incorrect operation of the aircraft electrical system, the inefficiency of voltage regulators RN-180M and the defectiveness of direct current generators GS-12T 3s. In the case of GS-12T 3s, the malfunction was due to the incorrect adjustment of the brushes' angle in relation to the magnetically neutral zone. Based on the new method developed in ITWL consisting in the measurement and correction of the brushes' angle in relation to the magnetically neutral zone of the commutating generator of a direct current, the above-mentioned generators were adjusted. Verification on the measurement stand and in real conditions (during engine test of Su-22) of transient state parameters of a direct current generators GS-12T 3s after the regulation, confirmed the airworthiness of the examined generators. It proves the efficiency and usefulness of the applied method in the operation process of aircraft. The described issues are essential in view of guaranteeing the airworthiness in aircraft operation and ensuring flight safety.

Keywords: aircraft, diagnostics, airworthiness, flight safety, electric power system, transient state, self-regulation, ageing, regulation, position angle of brushes in relation to magnetically neutral zone.

\section{OCENA SYSTEMÓW ELEKTROENERGETYCZNYCH PRĄDU STAŁEGO STATKU POWIETRZNEGO NA PODSTAWIE CHARAKTERYSTYK STANU NIEUSTALONEGO}

\section{Streszczenie}

W publikacji przedstawiono cel oraz istotę badania stanów przejściowych systemów elektroenergetycznych prądu stałego w odniesieniu do normatywnych charakterystyk stanu nieustalonego. Powyższe badania diagnostyczne poszczególnych węzłów prądu stałego statku powietrznego pozwalają na szybkie i skuteczne określenie zdolności ich układów zasilania elektrycznego do samoregulacji napięcia prądu stałego. Wieloletnie badania statków powietrznych wykonywane w Instytucie Technicznym Wojsk Lotniczych (ITWL) potwierdzają, że starzenie elementów sieci elektroenergetycznej wpływa na pogorszenie parametrów napięcia stanu nieustalonego. Na przykładzie wyników z prób naziemnych silnika wybranego samolotu Su-22 przedstawiono uzyskane przykładowe parametry stanów przejściowych $\mathrm{w}$ kolejnych latach jego eksploatacji, które potwierdzają powyższe stwierdzenie. Przedstawiono również wybrane wyniki badań realizowanych w czasie remontu weryfikacyjnego samolotów Su-22z przekroczonymi dopuszczalnymi progami normatywnymi zmian wartości amplitudy napięcia przy skokowym zwiększeniu obciążenia (impulsów zanikowych). Stwierdzonymi przyczynami wykrytych niesprawności były: niesprawna instalacja elektryczna samolotu, źle działające regulatory napięcia RN-180M oraz wadliwe działanie prądnic prądu stałego GS-12T 3s. W przypadku prądnic GS-12T 3s niesprawność wynikała z nieprawidłowego ustawienia w prądnicy kąta położenia szczotek względem strefy magnetycznie obojętnej. W oparciu o opracowaną w ITWL nową metodę pomiaru i korygowania kąta położenia szczotek względem strefy magnetycznie obojętnej komutatorowej prądnicy prądu stałego wykonano regulację powyższych prądnic. Weryfikacja na stanowisku pomiarowym i w warunkach rzeczywistych (w czasie próby silnika na samolocie Su-22) parametrów stanów przejściowych prądnic prądu stałego GS-12T 3s po regulacji potwierdziła zdatność do lotu badanych prądnic. Świadczy to o skuteczności i przydatności zastosowanej metody w procesie eksploatacji statków powietrznych. Przedstawiona problematyka jest istotna $\mathrm{z}$ punktu widzenia zapewnienia zdatności do lotu w procesie eksploatacji statków powietrznych i zapewnienia bezpieczeństwa lotów. 


\section{INTRODUCTION}

Aircraft electrical systems become more complicated, electrical wiring failures have become a huge concern in industry and government especially on aging platforms [1]. The technical challenges associated with the sustainment of electrical systems in aging aircraft deserve systematic study. Electrical systems, aviation electronics and many other systems are subject to wear and deterioration that can contribute to rising problems over time. The correct operation of electric power supply systems of the aircraft is indispensable to ensure the required parameters of the quality of electric energy. Their correct functioning depends on the quality of electric energy produced on board by generators and transmitted to certain aircraft systems. The malfunction of the electric power supply system is a direct threat to the proper operation of aircraft systems it supplies and thus, the threat to flight safety. Fast changes, collapses, rises, overvoltages and pin impulses belong to the most substantial disturbances in the aircraft power system. Therefore, the estimation of the technical condition of electric power systems is particularly important for aircraft operation. It is assumed that a component operates reliably when the wear does not exceed the acceptable (limit) values [2]. The above statement becomes particularly crucial in relation to ageing aeronautical engineering and ageing processes occurring in the electric power systems of the operated aircraft. The ageing significantly affects the reduction of dependability and durability of aircraft devices, drops of the dependability of on-board energy sources and poses a potential threat to flight safety. The aging of technical components of aircraft as an armament system proves of outstanding significance to reliability and safety of the whole system. The aging process is usually induced by many and various factors, just to mention mechanical, biological, climatic, or chemical ones. The aging is an irreversible process and considerably affects (i.e. reduces) reliability and lifetime of aeronautical equipment [3]. Thus, the broadly understood electric power system of the aircraft influences, by its technical condition frequently reduced due to ageing processes, on the reduction of the durability of all other systems [4]. For maximum utilization of distribution network without compromising the security and reliability of the supply system, determination of critical loading is crucial [5]. Therefore, providing the proper parameters of the quality of electric energy, that is the size group (the characteristics of stationary and transient states) characterizing the supply voltage we ensure the condition of a proper operation of the supplied systems of the aircraft. Failure to meet the correct ranges of values of the parameters of the quality of electric energy, set out in the standard [6, 7], produced by the on-board sources may result in disturbances of the operation of on-board systems, their damage or disengagement. Moreover, the failure of the electronic system often leads to a destructive failure or a horrible accident of the engineering system, such as the failure of the flight control system of an airplanes [8]. The example of the negative influence of the supply system on the on-board systems is the automatic activation of the fire protection system in Mi-8 helicopter, caused by electric interference in the form of voltage impulses [9]. The studies conducted by the ITWL confirmed that the most probable reason of the automatic activation (without the occurrence of fire) of the mentioned system was an incorrect development of the fire signal by the executive block SSP-FK-BI. The automatic activation of this block might be due to the instantaneous disturbances (decaying and overvoltage impulses) in the helicopter electric power supply network, which could be the cause of a false activation of fire protection system. The above example confirms that the correct functioning of electric power network of the aircraft depends on the proper operation of other on-board systems, and testing of electric energy nodes, owing to the necessity of preventing abnormalities in their operation, is a significant element in the operation of aircraft.

\section{DIAGNOSTICS OF NONSTATIONARY (TRANSIENT) STATES OF ELECTRIC POWER SYSTEMS OF A DIRECT CURRENT}

The basic source of supply in electric power systems of $\mathrm{Su}-22$ and $\mathrm{Mi}-8$ aircraft is a commutating generator of a direct current. In $\mathrm{Su}-22$ aircraft, the main source of supply of a direct current with the voltage of $28 \mathrm{~V}$ is two direct current generators GS-12T 3s. The generator GS-12T $3 \mathrm{~s}$ is a self-excited, six-pole electrical machine of a direct current with a parallel excitation. These generators are distinguished by a wide range of advantages but their usage also poses a substantial amount of problems concerning the operation. The generator GS-12T $3 \mathrm{~s}$ and its automatic control system was depicted in Fig. 1.

DC power systems are subject to strong dynamic interactions between the source and the loads $[10,11,12,13]$. Thus, the regular diagnostic tests of electric power systems of a direct current of the above-mentioned aircraft conducted during works associated with extending its overhauls directly impacts the flight safety in subsequent years of their operation.

During on-ground engine tests, besides the basic measurements of transient states such as the voltage and pulsation of a direct current, the measurement of the voltage of nonstationary (transient) states is taken occurring by the changes of loads in the onboard network. These tests are performed in accordance with the methodologies during engine tests developed in the ITWL. In ITWL, the tests of 
transient states of electric power nodes of aeroplanes on Su-22 aircraft during engine onground tests (Fig. 2) have been conducted for 18 years.

a)

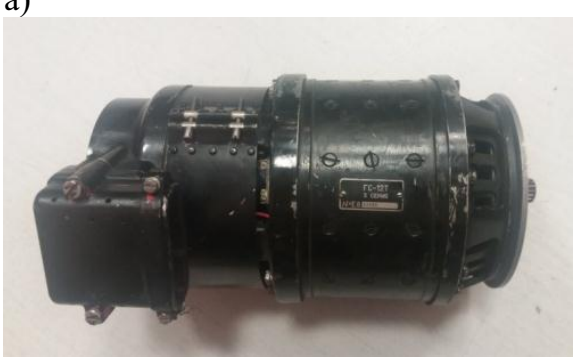

b)

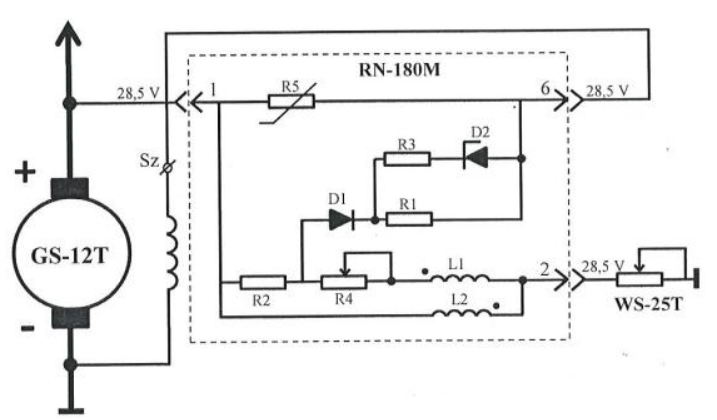

Fig. 1. The generator GS-12T 3s and its automatic control system a) view of the external generator GS-12T $3 \mathrm{~s}$ b) schematic diagram of the automatic generator control system (own work based on [14])

The change of current load of the electrical power supply system of the on-board networks on the examined $\mathrm{Su}-22$ and $\mathrm{Mi}-8$ aircraft is implemented by switching on and off the permanent electrical energy receivers installed aboard characterized by the maximum power consumption by their activation. Starting of the current load of the electrical power supply system is caused by voltage impulses - changes of voltage by the step drop or rise of voltage of generators triggered by rise or drop of voltage in direct current circuits. By a discrete increase of the load, there is a reduction of voltage and a decaying impulse is created, and by a discrete reduction of the load, there is an increase of voltage and the overvoltage impulse is generated.

The examples of the record of voltages over time in transient states for electric energy node of direct current generator GS-12T 3s by a step increase of load obtained during tests on Su-22 aircraft was depicted in Fig. 3 and Fig. 4. In both cases, by the change of load in the on-board generator, there are fluctuations of voltage, which falls twice below the reference level $24 \mathrm{~V}$.

According to the Defence Standard [6], the voltages of the nonstationary state is transformed into their equivalent step functions that are the rectangular substitute impulses of a direct current, reflecting the voltage impulses.

The parameter determined in a transient state is a value of the non-regulatory product of the time and voltage - the integral derived from the voltage over time which is converted into the so-called substitute impulse. For the above depicted transient states, the substitute impulses were calculated according to formula (1) and (2) for decaying impulses presented in Fig. 3

$$
\begin{aligned}
& S_{1}=\int_{0}^{\Delta t A C}[24-U(t)] d t \\
& S_{2}=\int_{0}^{\Delta t D F}[24-U(t)] d t
\end{aligned}
$$

and respectively formulas (3) and (4) for decaying impulses presented in Fig. 4.

$$
\begin{aligned}
& S_{1}=\int_{0}^{\Delta t A C}[24-U(t)] d t \\
& S_{2}=\int_{0}^{\Delta t C E}[24-U(t)] d t
\end{aligned}
$$

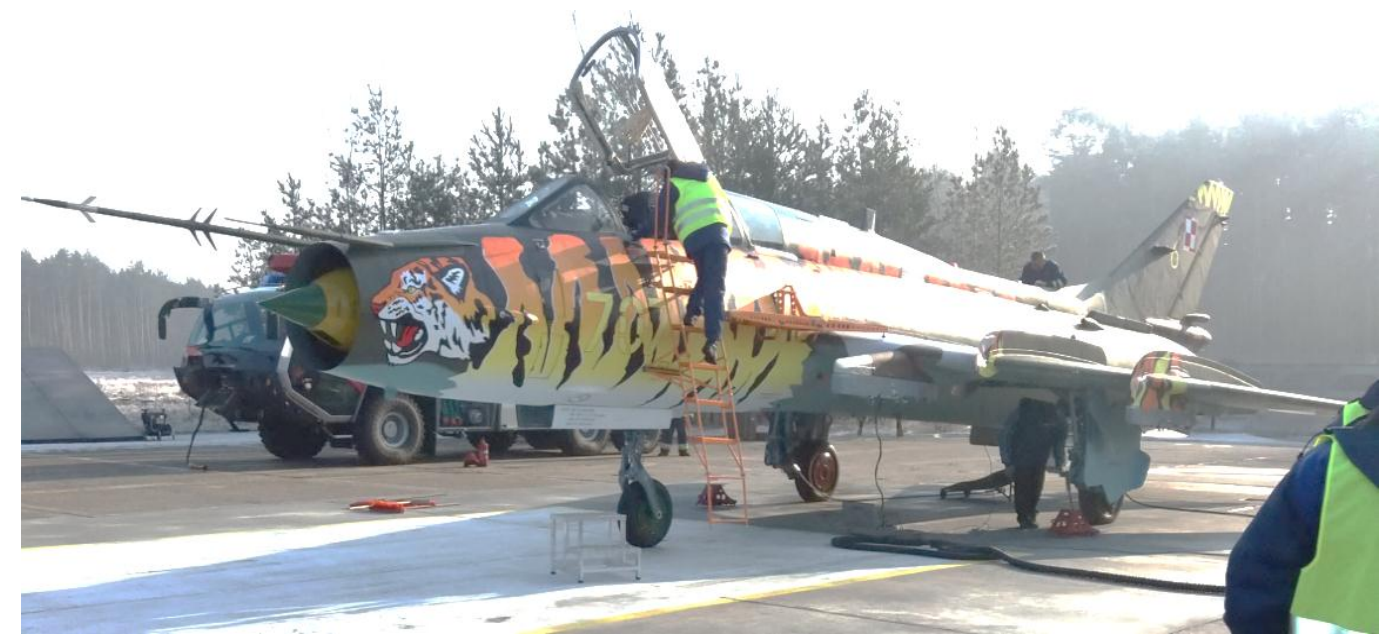

Fig. 2. Su-22 aircraft during engine on-ground test [own work] 


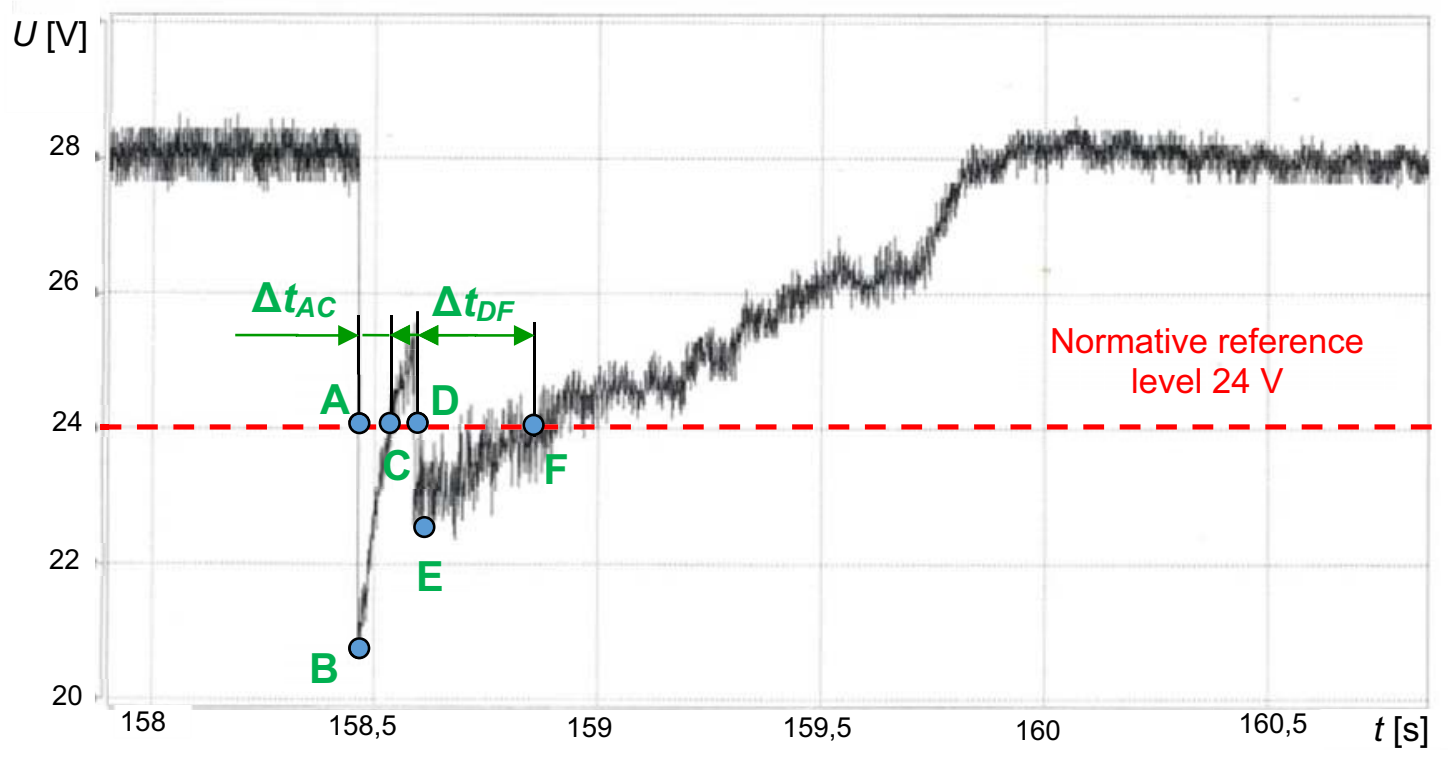

Fig. 3. Positive example from the tests of the transient state of a $28 \mathrm{~V}$ direct current supply system of Su-22 aircraft decaying impulses - by loading the electric energy node with the converter PTO-1000/1500M - A-B-C and D-E-F - record of changes of voltage in time - transient state (decaying impulses) [own work]

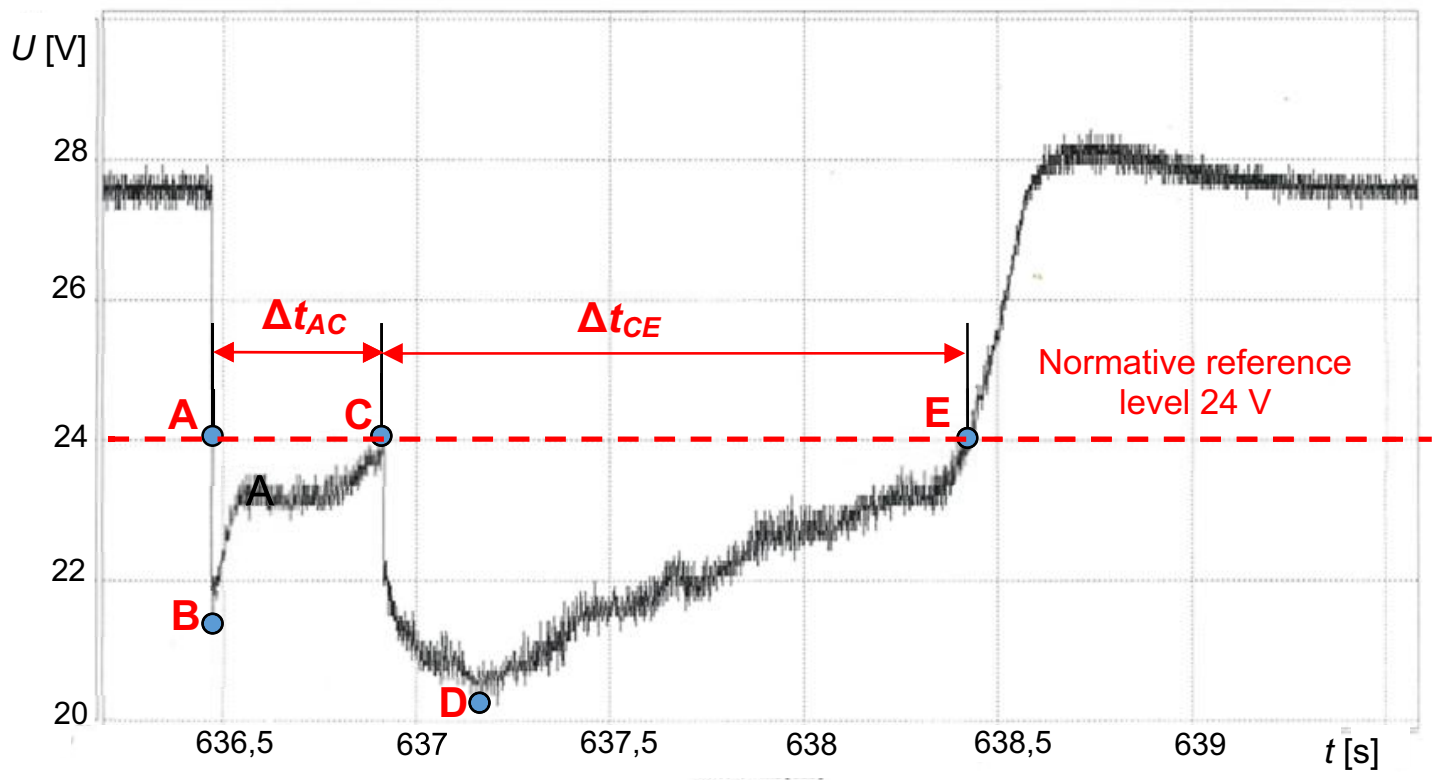

Fig. 4. Negative example from the tests of the transient state of a $28 \mathrm{~V}$ direct current supply system of Su-22 aircraft decaying impulses - by loading the electric energy node with the converter PTO-1000/1500M - A-B-C and C-D-E - record of changes of voltage in time - transient state (decaying impulses) [own work]

Then, as the equivalent step function rectangular substitute impulses are compared to standard characteristics of a transient state. Due to the fact that in the demonstrated samples of tests of a transient state there were observed fluctuations of the record of voltages, which exceeds the standard reference level $24 \mathrm{~V}$ twice - the substitute impulses $\mathrm{S}_{1}$ and $\mathrm{S}_{2}$ obtained during the analysis were compared one by one in Fig. 5 and Fig. 6. Compared to the characteristics of a transient state (NO-15-A200: 2016 Fig. 12 and 13) [6], the rectangular substitute impulses of a direct current, reflecting voltage impulses (substitute impulses $\mathrm{S}_{1}$ and $\mathrm{S}_{2}$ ), present the difference of values of the standard voltage of the reference level $24 \mathrm{~V}$ and the minimum voltage $U_{\min }$ of a given substitute impulse as well as its reduced time $t_{z}$, the value of which was calculated according to the formula (5).

$$
t_{z}=\frac{s}{24-U_{\min }}
$$


In case of the normal operation of the electric supply system of the voltage of a transient state (voltage impulses) converted into their equivalent step functions shall be within the limits specified in the Defence Standard [6] - depending on the applied load. In compliance with the abovementioned standard, the limit values specify the acceptable ranges of changes of equivalent step functions of the voltage of a direct current in electric power supply system from direct current generators with the voltage of $28 \mathrm{~V}$ or their rated parameters. If at least one of the substitute impulses goes beyond the limit value determined by a standard curve (suitable to the applied load), then the result of the test is negative. A transient state with a decaying impulse presented in Fig. 3. is the example of the proper operation of electric power network of a direct current generator on the examined aircraft. The analysis of measurements of transient states of generators' node of a $28 \mathrm{~V}$ direct current of Su-22 aircraft shows the graphical display of this state against the background of ranges of equivalent changes of step functions of a $28 \mathrm{~V}$ voltage of a direct current in electric power supply systems from direct current generators Fig. 5.

By the step increase of load, the resulting voltage drop in $28 \mathrm{~V}$ direct current network below the standard reference level for the resulting overvoltage impulses is short enough $\left(\Sigma \Delta \mathrm{t}_{\mathrm{N}}=\Delta \mathrm{t}_{\mathrm{AC}}+\Delta \mathrm{t}_{\mathrm{DF}}\right) \quad$ so that the obtained substitute impulses $\mathrm{S}_{1}=127 \mathrm{Vms}$ and $\mathrm{S}_{2}=177 \mathrm{Vms}$ (respectively $\mathrm{t}_{\mathrm{z} 1}=40 \mathrm{~ms}$ and $\mathrm{t}_{\mathrm{z} 2}=120 \mathrm{~ms}$ ) do not cross the standard curve of interval 4 (denoted by a red line) of acceptable change intervals of equivalent step functions of a direct current voltage in electric power system supplied from $28 \mathrm{~V}$ direct current generators [6].

A transient state with a decaying impulse presented in Fig. 3. is the example of the wrong operation of the electric power network of a direct current generator on the aircraft under examination. The analysis of measurements of transient states of generators' node of a $28 \mathrm{~V}$ direct current of $\mathrm{Su} 22$ aircraft shows the graphical display of this state against the background of ranges of equivalent changes of step functions of voltage of a direct current in electric power systems supplied from direct current generators - Fig. 6. By the step increase of load, the resulting voltage drop in $28 \mathrm{~V}$ direct current network below the standard reference level for the resulting overvoltage impulses is long enough $\left(\Sigma \Delta \mathrm{t}_{\mathrm{N}}=\Delta \mathrm{t}_{\mathrm{AC}}+\Delta \mathrm{t}_{\mathrm{CE}}\right)$ so that the obtained substitute impulses $\mathrm{S}_{1}=375 \mathrm{Vms}$ and $\mathrm{S}_{2}=2987 \mathrm{Vms}\left(\mathrm{t}_{\mathrm{z} 1}=150 \mathrm{~ms}\right.$ and $\mathrm{t}_{\mathrm{z} 2}=850 \mathrm{~ms}$ respectively) cross the standard curve of interval 4 (denoted by a red line) of acceptable change intervals of equivalent changes of step functions of voltage of a direct current in electric power systems supplied from $28 \mathrm{~V}$ direct current generators [6].

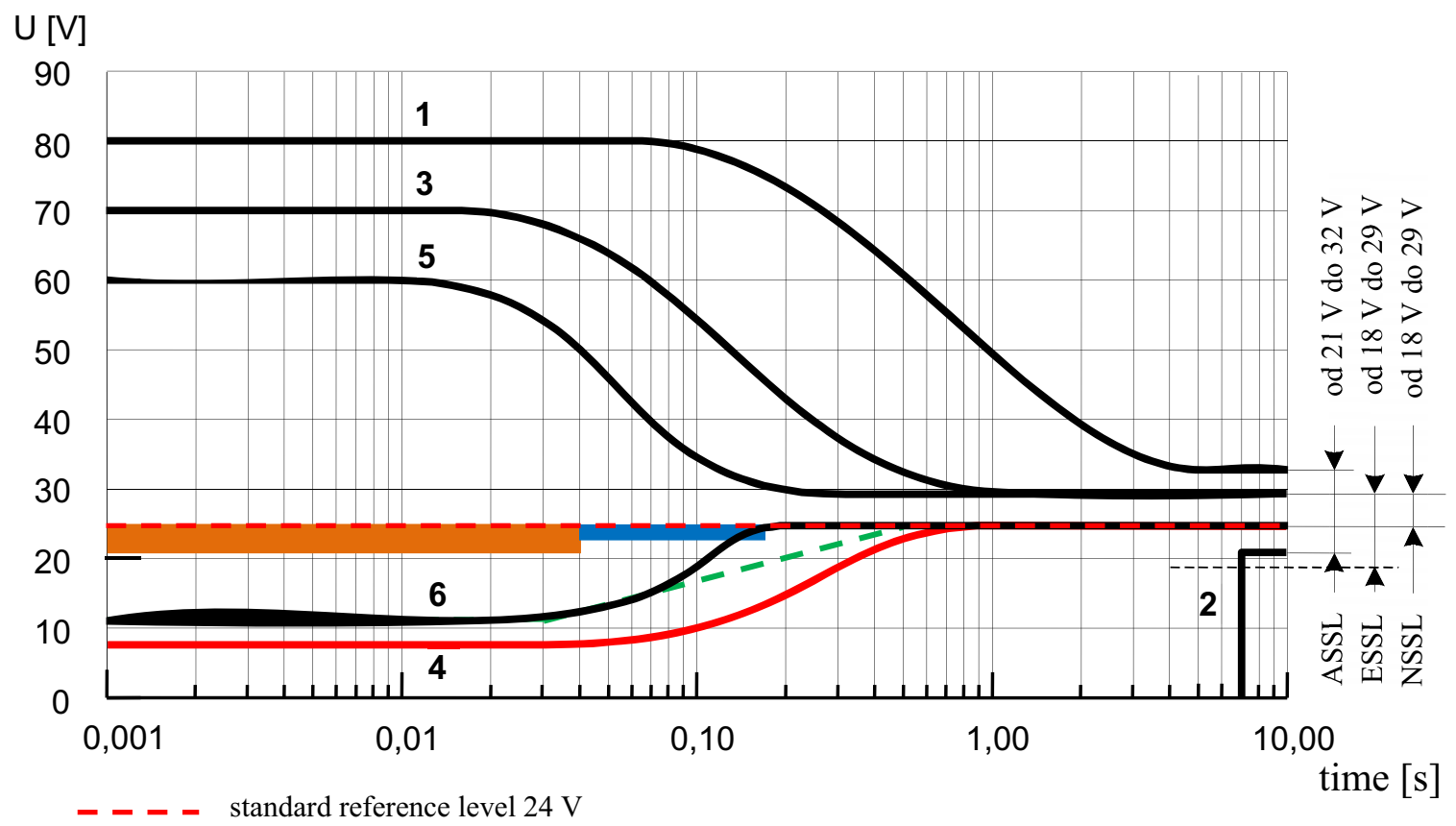

Parameters: $\quad$ acceptable, $\quad-$ rated (according to NO-15-A200: 2016 Fig. 12 and 13)

Substitute decaying impulse $\mathrm{S}_{1}$

Substitute decaying impulse $\mathrm{S}_{2}$

Fig. 5. Analysis of measurements of transient states of the node of $28 \mathrm{~V}$ direct current generators of Su-22 aircraft against the background of ranges of equivalent changes in step functions of voltage of a direct current in electric power supply systems from direct current generators (own work based on [6]) 


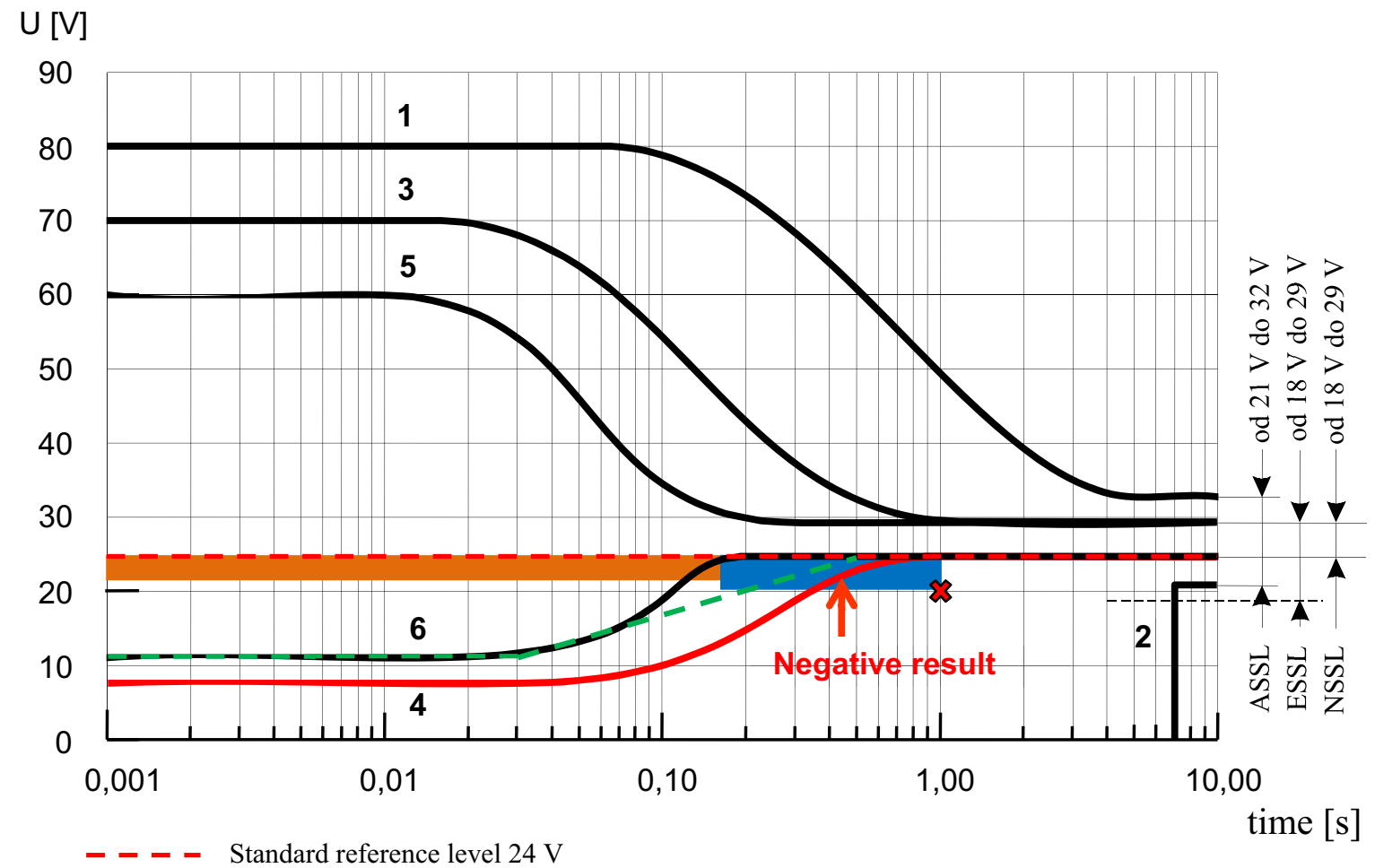

parameters: $\quad$ acceptable, $\quad$ rated (according to NO-15-A200: 2016 Fig. 12 and 13)

Substitute decaying impulse $\mathrm{S}_{1}$

Substitute decaying impulse $\mathrm{S}_{2}$

Marker denoting an extreme bottom point of the most ,unfavorable” rectangular substitute decaying impulse

Fig. 6. Analysis of measurements of the transient states of the node of $28 \mathrm{~V}$ direct current gene-rators of Su 22 aircraft against the background of ranges of equivalent changes in step functions of voltage of a direct current in electric power supply systems from direct current generators (own work based on [6])

\section{RESULTS OF TESTS ON TRANSIENT STATES OF A DIRECT CURRENT ELECTRIC POWER SYSTEM}

Based on many years of studies on $28 \mathrm{~V}$ direct current generators' nodes undertaken in the period of the operation of Su-22 aircraft, during the implementation of procedures consisting in increasing its service life, it can be stated that ageing of the elements of electric power network affects the deterioration of its properties. The analysis of data amassed from these tests provided information on direct current generators' nodes of Su-22 aircraft and enabled to assess their changes over a long period of time. Sample test results of a voltage transient states of particular generators' nodes of a direct current $28 \mathrm{~V}$ (No. 1 and No. 2) of Su-22 aircraft were compiled in Table 1.

The results of tests of voltage transient states of particular nodes of $28 \mathrm{~V}$ direct current generators
(No. 1 and No. 2) of Su-22 aircraft included in Table 1 against the background of rated and acceptable ranges of equivalent changes of step functions were shown in Fig. 7.

This figure presents graphically (in the form of markers defining the extreme bottom point of the rectangular substitute decaying impulse) the collected values of voltage impulses of particular nodes of the examined Su-22 aircraft in subsequent years of its operation. Both for a direct current node No. 1 as well as for No. 2 in 2007, the obtained values of voltage impulses did not exceed the rated limit values [6] but over the next years of operation they become deteriorating. Already after 5 years of operation (in 2012), in the case of node No. 2, they reached parameters exceeding the acceptable limit values [6]. 
Table 1. Measurement of transient states (with the applied load) of generators' nodes of a direct current $28 \mathrm{~V}$ of Su-22 aircraft in subsequent years of operation [own work]

\begin{tabular}{|c|c|c|c|c|c|c|c|c|c|c|c|c|}
\hline \multirow{6}{*}{ 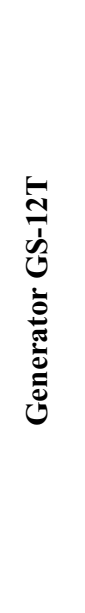 } & \multicolumn{12}{|c|}{ Years of taken measurements (year, month) } \\
\hline & \multicolumn{4}{|c|}{06.2007} & \multicolumn{4}{|c|}{05.2010} & \multicolumn{4}{|c|}{07.2012} \\
\hline & \multicolumn{2}{|c|}{$\begin{array}{l}\text { Measured } \\
\text { value }\end{array}$} & \multicolumn{2}{|c|}{$\begin{array}{l}\text { Calculated } \\
\text { value }\end{array}$} & \multicolumn{2}{|c|}{$\begin{array}{l}\text { Measured } \\
\text { value }\end{array}$} & \multicolumn{2}{|c|}{$\begin{array}{l}\text { Calculated } \\
\text { value }\end{array}$} & \multicolumn{2}{|c|}{$\begin{array}{l}\text { Measured } \\
\text { value }\end{array}$} & \multicolumn{2}{|c|}{$\begin{array}{l}\text { Calculated } \\
\text { value }\end{array}$} \\
\hline & 总 & 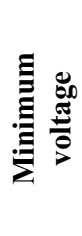 & 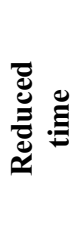 & 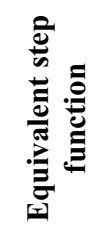 & 总 & 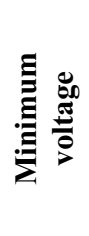 & 离 & 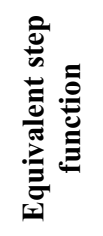 & 兽节 & 要害 & 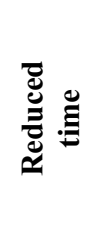 & 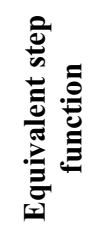 \\
\hline & $T$ & $\mathbf{U}_{\min }$ & $t_{z}$ & $\mathbf{S}$ & t & $\mathbf{U}_{\min }$ & $t_{z}$ & $\mathbf{S}$ & $\mathbf{t}$ & $\mathbf{U}_{\min }$ & $t_{z}$ & S \\
\hline & {$[\mathrm{ms}]$} & {$[\mathrm{V}]$} & {$[\mathrm{ms}]$} & [Vms] & {$[\mathrm{ms}]$} & {$[\mathrm{V}]$} & {$[\mathrm{ms}]$} & [Vms] & {$[\mathrm{ms}]$} & [V] & {$[\mathrm{ms}]$} & [Vms] \\
\hline \multirow{3}{*}{ No. 1} & 22 & 21.6 & 10.8 & 23.9 & \multirow{2}{*}{32} & \multirow{2}{*}{20.7} & \multirow{2}{*}{15.7} & \multirow{2}{*}{48.5} & 70 & 20.6 & 32.7 & 111.2 \\
\hline & 4 & 23.7 & 1.8 & 0.5 & & & & & 280 & 22.4 & 178.0 & 284.8 \\
\hline & \multicolumn{4}{|c|}{$\begin{array}{l}\text { in compliance with the } \\
\text { requirements [6] }\end{array}$} & \multicolumn{4}{|c|}{$\begin{array}{l}\text { in compliance with the } \\
\text { requirements [6] }\end{array}$} & \multicolumn{4}{|c|}{$\begin{array}{l}\text { in compliance with the } \\
\text { requirements [6] }\end{array}$} \\
\hline \multirow{3}{*}{ No. 2} & 20 & 21.6 & 10.4 & 24.9 & 34 & 20.4 & 16.4 & 59.2 & 192 & 20.4 & 74.9 & 269.5 \\
\hline & 12 & 23.4 & 6.7 & 4.0 & 24 & 23.5 & 12.5 & 6.3 & 958 & 20.7 & 522.5 & 1724.4 \\
\hline & \multicolumn{4}{|c|}{$\begin{array}{l}\text { in compliance with the } \\
\text { requirements [6] }\end{array}$} & \multicolumn{4}{|c|}{$\begin{array}{l}\text { in compliance with the } \\
\text { requirements [6] }\end{array}$} & \multicolumn{4}{|c|}{$\begin{array}{l}\text { not in compliance with the } \\
\text { requirements [6] }\end{array}$} \\
\hline
\end{tabular}

The above example confirms that transient states' parameters of direct current nodes of Su-22 aircraft deteriorate year after year. This may suggest that there is a potential possibility of the occurrence of incorrect functioning of direct current nodes of Su-22 aircraft during their daily operation. The results of tests carried out during follow-up overhaul of Su-22 aircraft prove the significance of the voltage transient states to ensure the airworthiness in operation of aircraft. They provided information on the current condition of direct current nodes of examined Su-22 aircraft after completed follow-up overhaul. Despite the completed overhaul of units, in several cases, their usage on Su-22 aircraft during engine tests was the reason for the exceeded permissible standard thresholds. It was found that the resulting decaying impulses are not compliant with the requirements of the standard [6]. To repair the aircraft, it was necessary to repeatedly replace the generators and voltage regulators and to repeat the tests multiple times after their repair. The sample results of measurements of transient states taken in Su-22 aircraft during subsequent tests after the follow-up overhaul were presented in Table 2.

The reasons of detected failures on several aircraft in subsequent trials were the inefficient aircraft electrical system, malfunction of voltage regulators $\mathrm{RN}-180 \mathrm{M}$ (in one case a defected isolation of the group of conductors and the overheated bundle of a regulator) and in vast majority a malfunction of direct current generators GS-12T 3s. The inefficiency in the form of increased decaying impulses, in case of direct current generators GS-12T 3s, results from the incorrect setting of the brushes' angle in relation to the magnetically neutral zone.

During the operation of Su-22 aircraft, there are various ageing processes of a direct current generator impacting the movement of the magnetically neutral zone, among others:

- change of the value of magnetic permeability (steel sheets of magnetic circuits of a rotor, stator, commutating and compensatory poles) causing a local dissipation and amplification of the line of magnetic field forces,

- change of the diameter of commutator resulting in the change of the conditions of commutation.

Therefore, the generators GS-12T 3s earmarked for the operation on Su-22 aircraft had to be regulated (the brushes were moved towards the neutral zone). 
a)

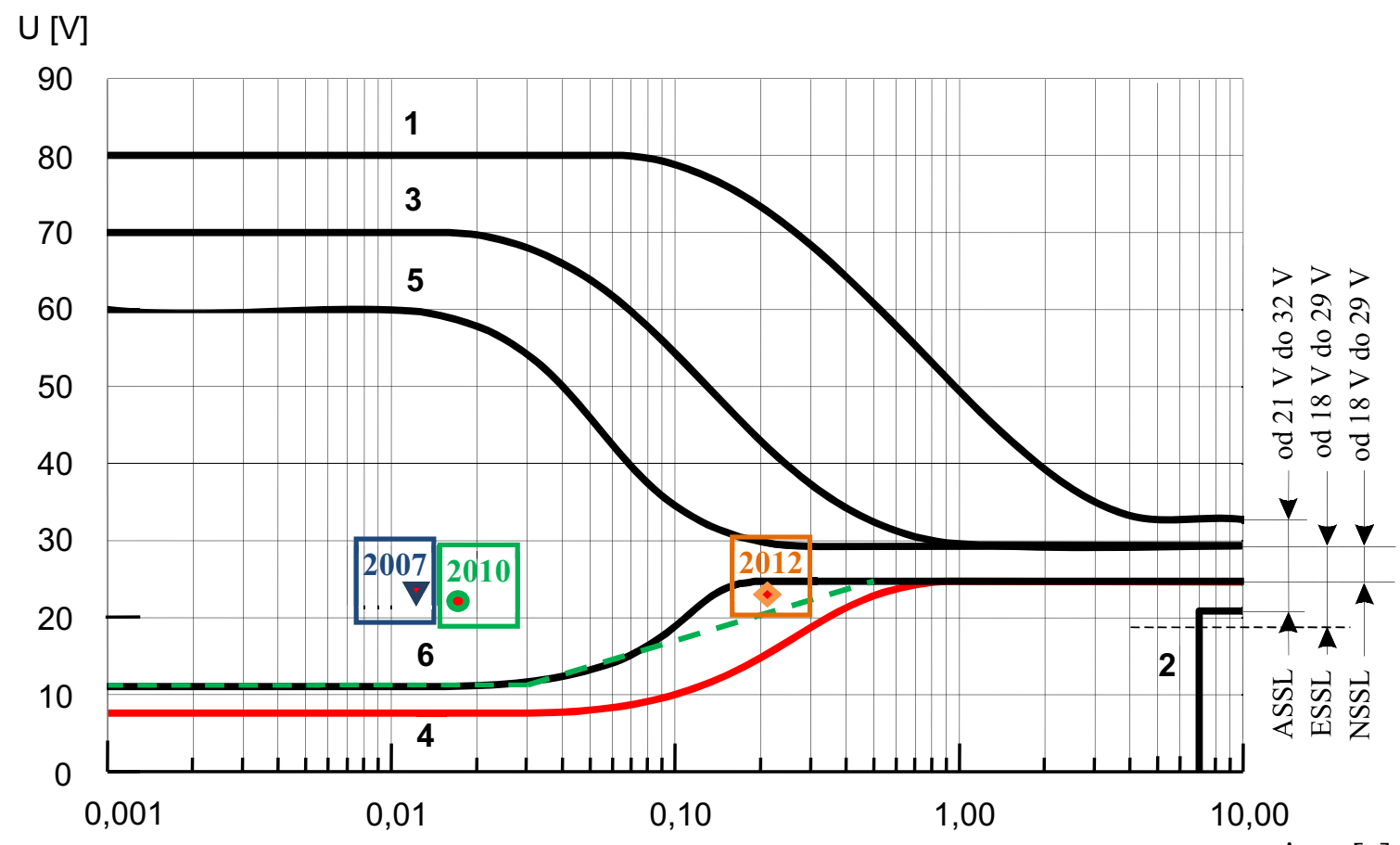

b)
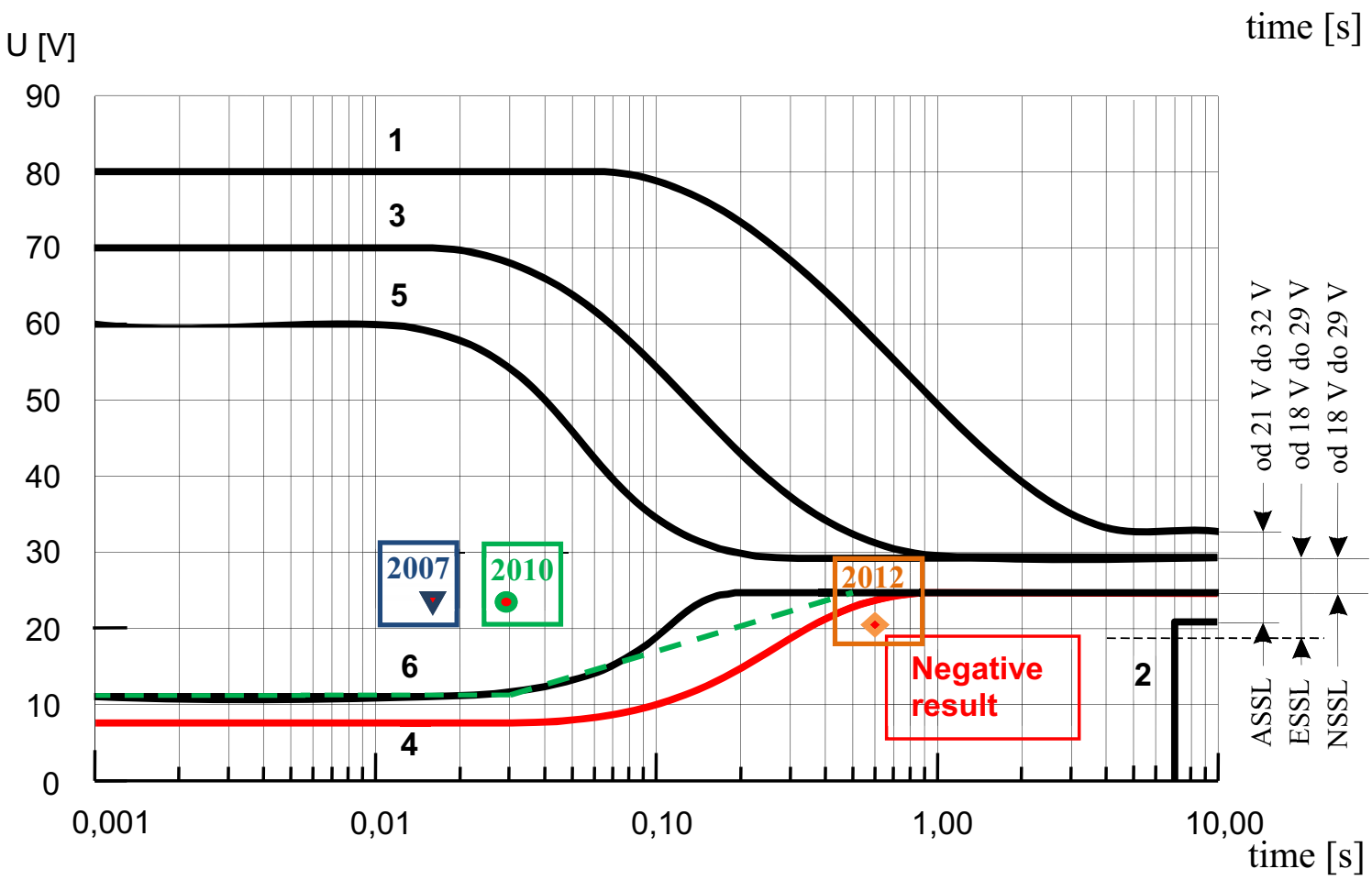

parameters: $\quad$ acceptable, $\quad$ rated (according to NO-15-A200: 2016 Fig. 12 and 13)

Markers determining the extreme bottom point of the rectangular substitute decaying impulse:

$\nabla$ - measurement taken in 2007

- measurement taken in 2010

- measurement taken in 2012

Fig. 7. Values of substitute decaying impulses in subsequent years of Su-22 aircraft operation for: a) node of a direct current No. 1 b) node of a direct current No. 2 (own work based on [6]) 
Table 2. Samples of results of measurements of transient states (with the applied load) taken in Su-22 aircraft during subsequent tests after the follow-up overhaul [own work]

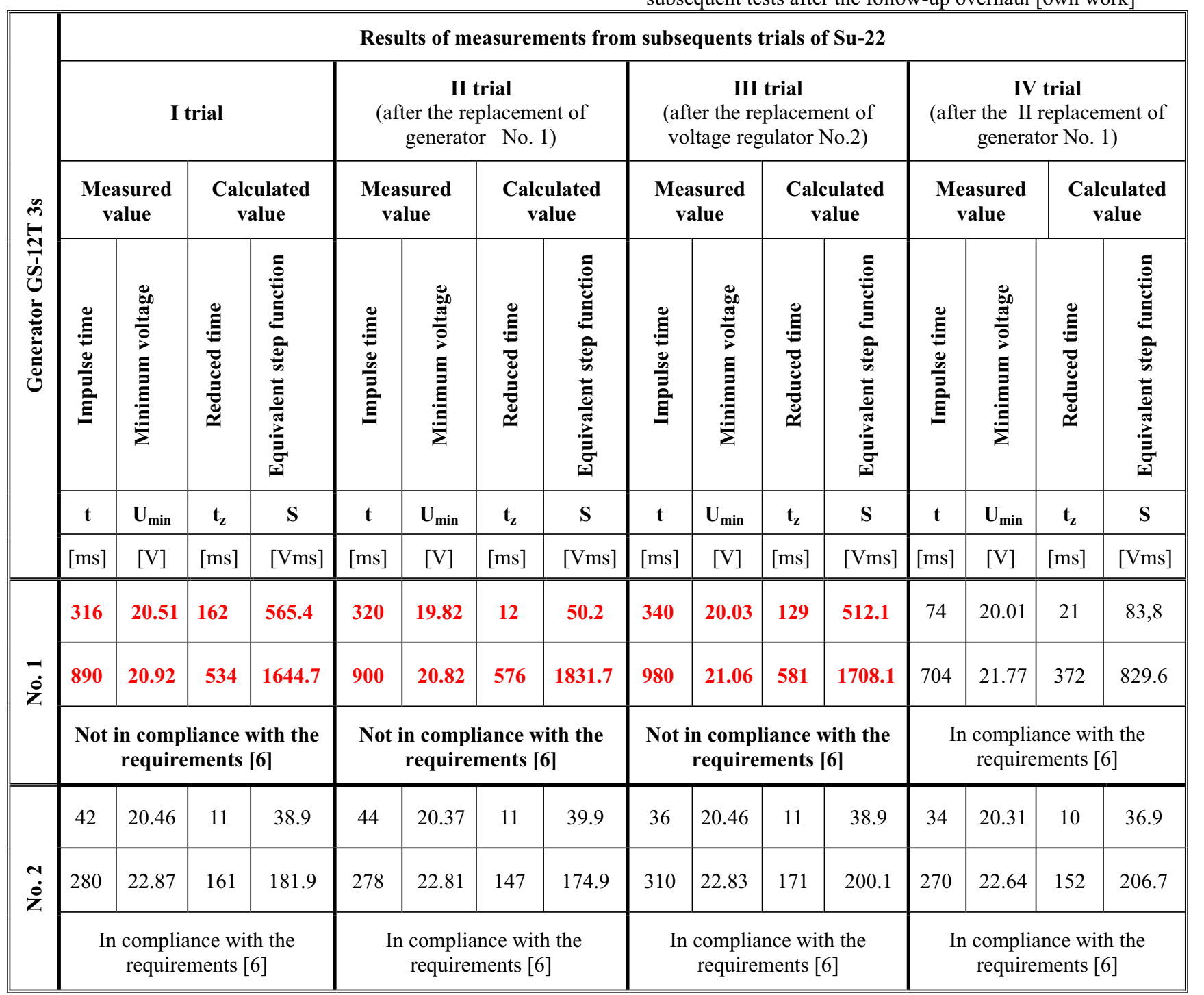

The above regulation was performed based on the ITWL's method for measurement and correction of brushes' angle on a direct current commutating generator [14] on the stand showed in Fig. 8.

Conducted preliminary tests on the measuring stand used to check generators in WZL-1 S.A proved that the regulation of generator brushes in relation to the neutral zone resulted in obtaining parameters consistent with the requirements of the standard [6] and the improvement of the selfregulation of the generator's voltage.
The correct adjustment of brushes' angle in relation to the magnetically neutral zone of direct current generators GS-12T ultimately was ultimately confirmed by the results of studies of transient states during engine test of Su-22 aircraft conducted in accordance with the methodology ITWL. The acquired results of measurements of transient states were compliant with the requirements of the standard [6]. These results were described in Table 3. 


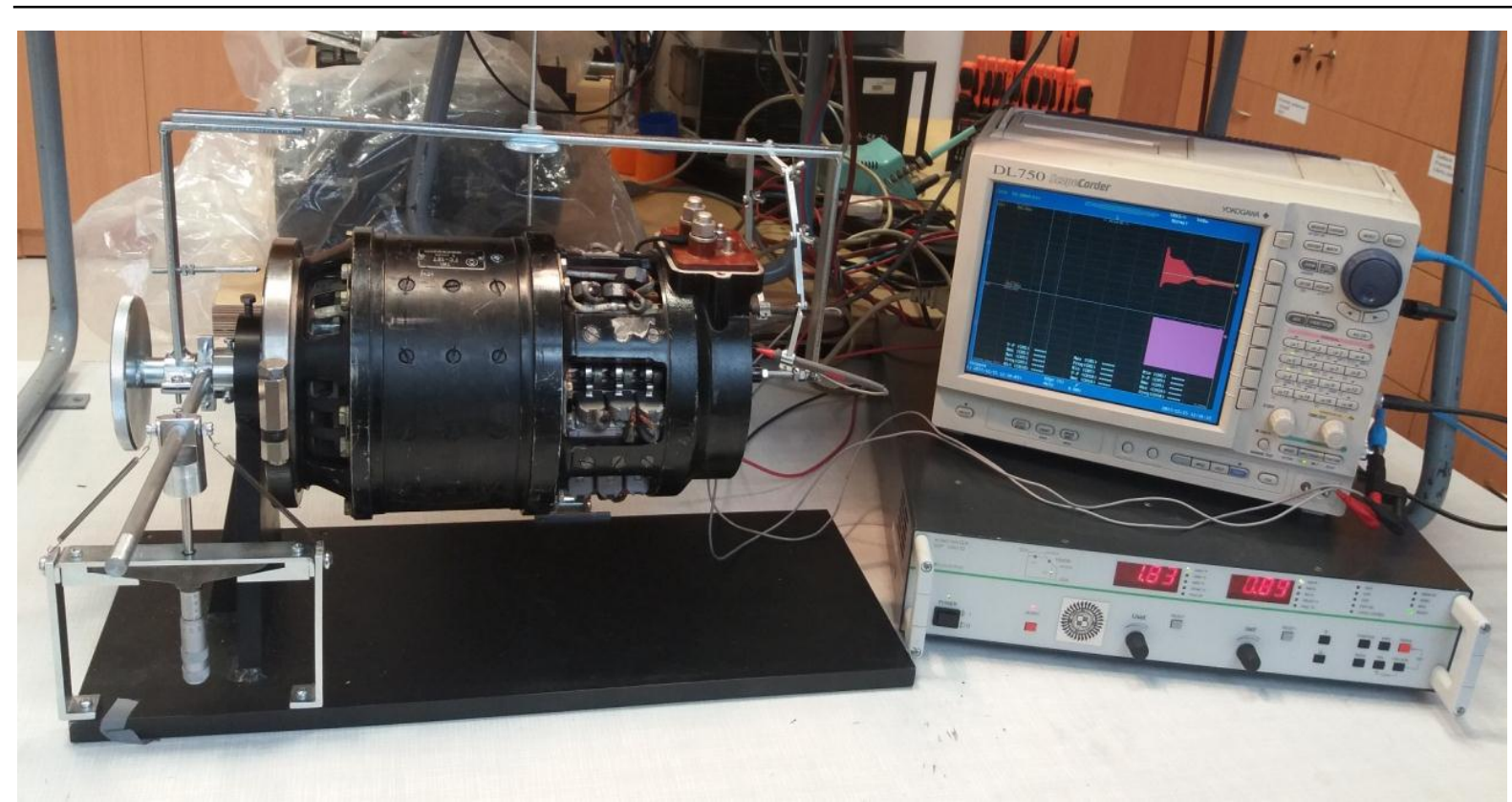

Fig. 8. Stand to check the brushes' angle of direct current generator GS-12T in relation to the neutral zone [own work]

Table 3. Results of the measurements of transient states (with the applied load) of Su-22 aircraft [own work]

\begin{tabular}{|c|c|c|c|c|}
\hline \multirow{5}{*}{$\begin{array}{c}\text { Generator } \\
\text { GS-12 3s }\end{array}$} & \multicolumn{4}{|c|}{ Results of measurements taken during SU-22 test } \\
\hline & \multicolumn{2}{|c|}{ Measured value } & \multicolumn{2}{|c|}{ Calculated value } \\
\hline & Impulse time & $\begin{array}{c}\text { Minimum } \\
\text { voltage }\end{array}$ & Reduced time & $\begin{array}{l}\text { Equivalent step } \\
\text { function }\end{array}$ \\
\hline & t & $\mathbf{U}_{\min }$ & $\mathbf{t}_{\mathbf{z}}$ & $\mathbf{S}$ \\
\hline & {$[\mathrm{ms}]$} & {$[\mathrm{V}]$} & {$[\mathrm{ms}]$} & {$[\mathrm{Vms}]$} \\
\hline \multirow{3}{*}{ No. 1} & 66 & 20.78 & 30 & 96.6 \\
\hline & 180 & 22.67 & 110 & 146.3 \\
\hline & \multicolumn{4}{|c|}{ In compliance with the requirements [6] } \\
\hline \multirow{3}{*}{ No. 2} & 190 & 19.74 & 51 & 217.3 \\
\hline & 392 & 21.93 & 218 & 451.3 \\
\hline & \multicolumn{4}{|c|}{ In compliance with the requirements [6] } \\
\hline
\end{tabular}

\section{SUMMARY}

The presented examples of failures indicate the importance of the described issue for the safety of flights and imply that testing transient states of electric power nodes is a fundamental element in the process of ensuring airworthiness in aircraft operation. The above statement takes on an added importance in view of the ageing changes of electric power systems of aircraft. The parameters of substitute impulses of direct current nodes of Su-22 aircraft statistically deteriorate year by year. It is illustrated in the results of measurements of transient states found in the ITWL during the implementation of methodologies associated with prolonging the service life of aircraft in subsequent years of their operation.

Conducted tests and analyses defining the possibility of the self-regulation of direct current electric power supply system of Su-22 aircraft in compliance with the requirements of the Defence Standard NO-15-A200: 2016 proved that:

- value of the decaying substitute impulse of a direct current affects the period of serviceability of direct current power supply nodes of aircraft,

- big diversification of properties of particular subassemblies of direct current nodes found during engine tests of Su-22 aircraft does not guarantee its full replaceability,

- taking into consideration the presented influence of time on the results of obtained transient states there is a potential possibility of the incorrect work of direct current nodes of Su-22 aircraft during subsequent operation,

- one of the reasons of the inefficiency of electric power nodes of $\mathrm{Su}-22$ aircraft was the malfunction of a direct current generator GS-12T 3s, the inefficiency in the form of increased decaying impulses resulted in the improper adjustment of brushes' angle in the 
generator in relation to the magnetically neutral zone,

- verification on the measuring stand and in real conditions, during engine test of Su-22 aircraft, parameters of transient states of direct current generators GS12T 3s after regulation (brushes' angle in relation to the magnetically neutral zone) confirmed the efficiency and usefulness of the applied method in operation of aircraft.

The presented diagnostic tests of direct current electric power systems of aircraft enable to quickly and efficiently determine the capability of the electric power system of particular nodes to selfregulate the direct current voltage.

Taking the above into account, a regular diagnostics and evaluation of direct current electric power systems of aircraft in the area of a transient state will enable the improvement of the operation of direct current nodes and will affect the safety of flights.

\section{REFERENCES}

1. Wang P. Civil aircraft electrical power system safety assessment: issues and practices. Kidlington, Oxford, Cambridge, Ma: Butterworth-Heinemann, 2017.

2. Zieja M, Ważny M, Stępień S. Outline of a method for estimating the durability of components or device assemblies while maintaining the required reliability level. Eksploatacja i Niezawodność-Maintenance and Reliability. 2018; 20(2): 260-266. http://dx.doi.org/10.17531/ein.2018.2.11

3. Żurek J, Kaleta R, Zieja M. An application of characteristic function in order to predict reliability and lifetime of aeronautical hardware. Conference ICNAAM), Rhodes, GREECE 2015, Proceedings Of The International Conference On Numerical Analysis And Applied Mathematics 2015 (Icnaam-2015) Book Series: AIP Conference Proceedings 2016; 1738.

4. Gębura A, Tokarski T. Cechy diagnostyczne parametrów napięcia wyjściowego lotniczych prądnic pokładowych prądu stałego. Zeszyty Naukowe Politechniki Rzeszowskiej. 2004; 213: 239-340.

5. Krishan R, Verma A, Mishra S. Loadability analysis of DC distribution systems. International Journal Of Electrical Power \& Energy Systems. 2018; 103:176184. https://doi.org/10.1016/j.ijepes.2018.05.019

6. Norma Obronna NO-15-A200: 2016 - Wojskowe statki powietrzne. Pokładowe układy zasilania elektrycznego. Podstawowe parametry, wymagania i badania.

7. ISO 1540:2006 Aerospace - Characteristic of aircraft electrical systems.

8. He L, Yin C, Peng W, Yuan R, Huang H-Z. Reliability and risk assessment of aircraft electric systems. Eksploatacja i Niezawodność - Maintenance and Reliability. 2014; 16(4): 497-506.

9. Szelmanowski A, Zieja M, Głyda K, Tokarski T. Research method of dynamic capability of an actuating block of the SSP-FK aircraft fire suppression system in false alarm aspect. Journal of KONES. 2016; 23: 525-532.

https://doi.org/10.5604/12314005.1216482

10. Riu D, Sautreuil M, Retiere N, Sename O. Control and design of DC grids for robust integration of electrical devices. Application to aircraft power systems, International Journal Of Electrical Power \& Energy Systems. 2014; 58: 181-189.

11. Emadi A, Ehsani M. Aircraft power systems: technology, state of the art and future trends, IEEE Aerospace and Electronic Systems Magazine. 2000: $15: 28-32$.

12. Gupta JB. Electrical Machines (AC \& DC Machines), S. K. Kataria \& Sons, 2010.

13. Gupta JB. Theory \& Performance of Electrical Machines, S.K. Kataria \& Sons, 2015.

14. Tokarski T, Kalisiak M. Opracowanie projektów stanowiska i metodyki do sprawdzenia położenia szczotek prądnicy prądu stałego GS-12T względem strefy neutralnej, BT ITWL 8863/50, Warszawa, 2017.

Received 2018-08-22

Accepted 2018-12-14

Available online 2018-12-17

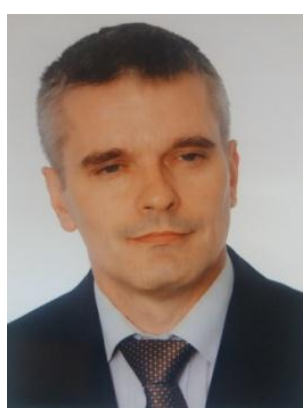

Tomasz TOKARSKI

is a graduate of Warsaw University of Technology where he studied at Faculty of Production Engineering. His scientific fields concerns among electric power systems in aircraft. 